\title{
Interstitial lung disease in suggestive forms of connective tissue disease
}

\author{
Doença intersticial pulmonar em formas sugestivas \\ de doença do tecido conectivo
}

\section{Aryeh Fischer}

\begin{abstract}
Patients with the characterizable forms of connective tissue disease (CTD) are at risk for developing interstitial lung disease (ILD), and there is a growing appreciation that ILD can be the first or only clinically relevant manifestation of an underlying CTD. ${ }^{(1-3)}$ Less is understoodand there is far greater controversy-about ILD associated with suggestive or "undifferentiated" forms of CTD. ${ }^{(2,3)}$
\end{abstract}

In the present issue of the Brazilian Journal of Pulmonology, Pereira et al. review the clinical scenario of autoantibody positivity in ILD and discuss how these serologic tests may be interpreted. ${ }^{(4)}$ In addition, they provide useful insights into the evaluation of patients with ILD suspected of having occult forms of CTD. Finally, the authors argue in favor of implementing the concepts that have been put forth in a recent commentary on "lung-dominant CTD" (5): a proposed, provisional category that describes ILD patients with an autoimmune flavor that fall short of meeting established criteria of any of the characterizable forms of CTD.

ldentifying occult CTD in patients presenting with what is initially considered to be an idiopathic interstitial pneumonia (IIP) can be challenging. Sometimes patients that subsequently develop a classifiable CTD cannot be identified before the specific systemic manifestations of the CTD appear. There is no universally accepted approach to these evaluations, and current practice includes an assessment for extrathoracic features of CTD, testing of a broad array of circulating autoantibodies, and consideration of specific radiographic and histopathologic features. ${ }^{(2,6)}$ Various centers have also found that a multidisciplinary evaluation-including rheumatologic consultation-can be useful. ${ }^{(7-9)}$

A number of recent studies have shown that patients with IIP often have subtle extrathoracic or other clinical features suggestive of an underlying autoimmune process and yet do not meet established criteria for any of the characterizable forms of CTD. ${ }^{(9-17)}$ Sometimes these subtle symptoms or signs occur in the absence of serologic abnormalities, or a serum autoantibody known to be highly specific for a certain CTD (e.g. anti-Jo-1 with the antisynthetase syndrome) may be present without typical systemic or extrathoracic features. Other scenarios exist whereby specific radiologic or histopathologic features are suggestive of an underlying CTD and yet the absence of extrathoracic or serologic findings precludes reliable classification as CTD-ILD.

In an area without consensus regarding terminology, the terms "undifferentiated CTD" (UCTD), ${ }^{(10,16)}$ "lung-dominant CTD"(5) and "autoimmune-featured ILD"(17) have been used to describe such patients with suggestive forms of CTD-ILD. Each of these categories has a unique set of proposed criteria, represent the ideas of investigative teams from distinct ILD referral centers, and have yet to be prospectively validated.

\section{UCTD}

The first descriptions of "undifferentiated diseases" were made in the late 1960's by Sabo. ${ }^{(18)}$ In 1980, LeRoy et al. proposed the concept of "undifferentiated connective tissue syndromes" to define early rheumatic disease mainly manifested by the presence of Raynaud's phenomenon and digital edema. ${ }^{(19)}$ Subsequently, UCTD has been defined as symptoms and signs suggestive of a CTD (e.g., arthralgias or arthritis, Raynaud's phenomenon, leukopenia, anemia, and dry eyes or dry mouth) with antinuclear antibody positivity, but not fulfilling existing classification criteria for a specific CTD. ${ }^{(20)}$ Approximately 60\% of the patients with UCTD will remain "undifferentiated," and, in the minority that develops a classifiable CTD, it usually does so within the first 5 years after the UCTD diagnosis. ${ }^{(20)}$ Although UCTD may evolve into any CTD, it most often evolves into systemic lupus erythematosus. An important distinguishing characteristic of UCTD is the absence of major organ involvement or damage. ${ }^{(20)} \ln 2007$, 
a broader set of UCTD criteria were proposed and retrospectively applied to a cohort of patients with IIP evaluated at an ILD referral center. ${ }^{(16)}$ Those defined as having UCTD were more likely to be female, younger, non-smokers and more likely to have radiographic and histopathologic evidence of non-specific interstitial pneumonia (NSIP). As nearly $90 \%$ of those with NSIP were defined as UCTD-ILD, the authors suggested that most patients with "idiopathic" NSIP might actually have an autoimmune disease and that idiopathic NSIP may be the lung manifestation of UCTD. ${ }^{16)}$ Corte et al. explored the clinical relevance of these broader UCTD criteria in a cohort of IIP patients from their ILD referral center. ${ }^{(10)}$ In their retrospective study, CTD features were found to be quite common; 31\% of NSIP cases and 13\% of patients with idiopathic pulmonary fibrosis (IPF) fulfilled the traditional UCTD criteria, and an astounding 71\% of NSIP cases and 36\% of IPF patients fulfilled the broader, less specific UCTD set of criteria. The clinical relevance of these classification schemes was called into question, as the diagnosis of UCTD by either set of criteria had no prognostic significance. ${ }^{(10)}$

\section{Autoimmune-featured ILD}

Vij et al. described a cohort of UIP-predominant ILD patients retrospectively identified as having a suggestive form of CTD-ILD. ${ }^{(17)}$ Among 200 patients evaluated in an ILD referral center, 63 were considered to have "autoimmune-featured ILD”. A classification of autoimmune-featured ILD required the presence of a sign or symptom suggestive of a CTD and a serologic test reflective of an autoimmune process. The cohort that met their case definition of autoimmune-featured ILD had a demographic profile resembling that of IPF: most were older (mean age of 66 years) and male. The most common clinical symptoms were dry eyes, dry mouth, or gastroesophageal reflux disease. In that cohort, 75\% of the patients with autoimmune-featured ILD had a lung injury pattern of UIP and similar overall survival to that of IPF patients and worse than in patients with classifiable forms of CTD-ILD. ${ }^{(17)}$

\section{lung-dominant CTD}

In 2010, Fischer et al. proposed the provisional classification of "lung-dominant CTD". ${ }^{(5)}$ The concept-and this classification-was meant to be applied to patients with ILD who fail to meet criteria for a characterizable CTD, yet have an "autoimmune flavor" to their disease as manifested by specific autoantibodies or histopathologic features. The presence of objective extrathoracic features is important, but their absence should not preclude a classification of lung-dominant CTD. ${ }^{(5)}$ Benefits of such a classification scheme include: 1 ) objective and measurable criteria; 2) exclusion of non-specific symptoms (such as dry eyes, myalgia, arthralgia, or gastroesophageal reflux disease), non-specific inflammatory markers, and low-titer, less specific autoantibodies; 3) a notion that surveillance for the development of characterizable CTD is warranted; and 4) an emphasis that such a classification provides a framework by which natural history, pathobiology, treatment, and prognostic studies can be implemented. ${ }^{(5)}$

\section{Statement of the problem}

Because of the generally improved outcomes associated with CTD-ILD and because different treatment approaches are often implemented in patients with CTD-ILD, determining whether these suggestive forms of CTD-ILD represent a spectrum of CTD-ILD-rather than IIP-is important. In essence, it is important to know whether these suggestive forms of CTD-ILD have a similar natural history as the classifiable forms of CTD-ILD and whether the approach to their management should be similar to that of CTD-ILD or to that of IIP. Current strategies for identifying and classifying these patients are controversial and inadequate, there is far too little interdisciplinary dialogue in this arena, and the advancement of this field would be well served by efforts to bridge these divides. Furthermore, the lack of consensus regarding terminology and the varying sets of existing classification criteria limit the ability to conduct multicenter and multidisciplinary prospective studies needed to answer the many fundamental questions about this ILD subgroup.

\section{A path forward}

In an effort to move beyond the current impasses and address these areas of controversy, the American Thoracic Society/European Respiratory Society Task Force-“An International Working Group on Undifferentiated Forms of CTD-ILD”has been recently formed. This Task Force is 
comprised of an international, multidisciplinary panel of CTD-ILD experts, including investigators from the centers that have put forth the differing existing criteria for UCTD, lung-dominant CTD, and autoimmune-featured ILD. The primary objective of the Task Force is to develop consensus regarding the nomenclature and criteria for the classification of suggestive forms of CTD-lLD. The Task Force will also identify key areas of uncertainty that are worthy of further research in this cohort. Once there is international and multidisciplinary consensus surrounding the nomenclature and classification criteria of these suggestive forms of CTD-ILD, the requisite platform will be in place to enable the much-needed prospective, multicenter, and multidisciplinary studies to further our understanding of this subgroup of lLD.

\section{Aryeh Fischer \\ Associate Professor of Medicine, National Jewish Health, Denver, C0, USA}

\section{References}

1. Cottin V. Interstitial lung disease: are we missing formes frustes of connective tissue disease? Eur Respir J. 2006;28(5):893-6. http://dx.doi. org/10.1183/09031936.00101506 PMid:17074915

2. Fischer A, du Bois R. Interstitial lung disease in connective tissue disorders. Lancet. 2012;380(9842):689-98. http:// dx.doi.org/10.1016/S0140-6736(12)61079-4

3. Cottin V. Interstitial lung disease. Eur Respir Rev. 2013;22(127):26-32. http://dx.doi. org/10.1183/09059180.00006812 PMid:23457161

4. Pereira DA, Kawassaki AM, Baldi BG. Interpretation of autoantibody positivity in interstitial lung disease and lung-dominant connective tissue disease. J Bras Pneumol. 2013;39(6):728-741.

5. Fischer A, West SG, Swigris JJ, Brown KK, du Bois RM. Connective tissue disease-associated interstitial lung disease: a call for clarification. Chest. 2010;138(2):251-6. http://dx.doi.org/10.1378/chest.10-0194 PMid:20682528 PMCid:PMC3662187

6. Fischer A, du Bois RM. A Practical Approach to Connective Tissue Disease-Associated lung Disease. In: Baughman RP, du Bois RM, editors. Diffuse Lung Disease---A practical approach. 2nd ed. New York: Springer; 2012. p. 217-37. http://dx.doi.org/10.1007/978-1-4419-9771-5_12

7. Castelino FV, Goldberg H, Dellaripa PF. The impact of rheumatological evaluation in the management of patients with interstitial lung disease. Rheumatology (Oxford). 2011;50(3):489-93. http://dx.doi.org/10.1093/ rheumatology/keq233 PMid:20685802
8. Fischer A. Interstitial lung disease: a rheumatologist's perspective. J Clin Rheumatol. 2009;15(2):95-9. http://dx.doi.org/10.1097/RHU.0b013e31819b715d PMid:19265357

9. Mittoo S, Gelber AC, Christopher-Stine L, Horton MR, Lechtzin N, Danoff SK. Ascertainment of collagen vascular disease in patients presenting with interstitial lung disease. Respir Med. 2009;103(8):1152-8. http:// dx.doi.org/10.1016/j.rmed.2009.02.009 PMid:19304475

10. Corte TJ, Copley SJ, Desai SR, Zappala CJ, Hansell DM, Nicholson AG, et al. Significance of connective tissue disease features in idiopathic interstitial pneumonia. Eur Respir J. 2012;39(3):661-8. http://dx.doi. org/10.1183/09031936.00174910 PMid:21920896

11. Fischer A, Meehan RT, Feghali-Bostwick CA, West SG, Brown KK. Unique characteristics of systemic sclerosis sine scleroderma-associated interstitial lung disease. Chest. 2006;130(4):976-81. http://dx.doi.org/10.1378/ chest.130.4.976 PMid:17035427

12. Fischer A, Pfalzgraf FJ, Feghali-Bostwick CA, Wright TM, Curran-Everett D, West SG, et al. Anti-th/to-positivity in a cohort of patients with idiopathic pulmonary fibrosis. J Rheumatol. 2006;33(8):1600-5. PMid:16783860

13. Fischer A, Solomon JJ, du Bois RM, Deane KD, Olson AL, Fernandez-Perez ER, et al. Lung disease with anti-CCP antibodies but not rheumatoid arthritis or connective tissue disease. Respir Med. 2012;106(7):1040-7. http:// dx.doi.org/10.1016/j.rmed.2012.03.006 PMid:22503074 PMCid:PMC3753791

14. Fischer A, Swigris JJ, du Bois RM, Groshong SD, Cool CD, Sahin $\mathrm{H}$, et al. Minor salivary gland biopsy to detect primary Sjogren syndrome in patients with interstitial lung disease. Chest. 2009;136(4):1072-8. http://dx.doi.org/10.1378/ chest.08-2839 PMid:19429722 PMCid:PMC3662204

15. Fischer A, Swigris JJ, du Bois RM, Lynch DA, Downey GP, Cosgrove GP, et al. Anti-synthetase syndrome in ANA and anti-Jo-1 negative patients presenting with idiopathic interstitial pneumonia. Respir Med. 2009;103(11):1719-24. http://dx.doi.org/10.1016/j. rmed.2009.05.001 PMid:19497723 PMCid:PMC2857337

16. Kinder BW, Collard HR, Koth L, Daikh DI, Wolters PJ, Elicker $\mathrm{B}$, et al. Idiopathic nonspecific interstitial pneumonia: lung manifestation of undifferentiated connective tissue disease? Am J Respir Crit Care Med. 2007;176(7):691-7. http:// dx.doi.org/10.1164/rccm.200702-2200C PMid:17556720 PMCid:PMC1994238

17. Vij R, Noth 1, Strek ME. Autoimmune-featured interstitial lung disease: a distinct entity. Chest. 2011;140(5):1292-9. http://dx.doi.org/10.1378/chest.10-2662 PMid:21565966 PMCid:PMC3205845

18. Sabo 1. The lanthanic or undifferentiated collagen disease. Hiroshima J Med Sci. 1969;18(4):259-64. PMid:5375831

19. LeRoy EC, Maricq HR, Kahaleh MB. Undifferentiated connective tissue syndromes. Arthritis Rheum. 1980;23(3):341-3. http://dx.doi.org/10.1002/ art.1780230312 PMid:7362686

20. Mosca M, Tani C, Carli L, Bombardieri S. Undifferentiated CTD: a wide spectrum of autoimmune diseases. Best Pract Res Clin Rheumatol. 2012;26(1):73-7. http:// dx.doi.org/10.1016/j.berh.2012.01.005 PMid:22424194 